\title{
THE IMPACT OF TECHNOLOGY EVALUATION PROGRAMME ON AGRICULTURAL PRODUCTIVITY IN ARMENIA
}

\author{
Davit Alaverdyan $^{1 *}{ }$, Henrietta Nagy ${ }^{1}$, Ira Panosyan ${ }^{2}$, Olagunju Kehinde ${ }^{1}$ \\ 'Szent István University, Gödöllő, Hungary \\ ${ }^{2}$ Armenian National Agrarian University, Yerevan, Armenia
}

\begin{abstract}
The importance of innovative technologies in bringing about sustainable development in agriculture cannot be overemphasized in today's world. Concerted efforts have been made by international organizations, ministries of agriculture and extension agents to ensure that farmers have access to these new technologies. Therefore, this study examined the role of technology as a guarantee of sustainable agricultural development in Armenia. The aim of this paper is to find out in what ways this specific technological program in Armenia could contribute to the sustainable development of agriculture and how the innovations applied in agriculture could improve the quality of products and improve the efficiency of production. Various technology programmes from 2001-2013 were critically examined using narratives based on the data obtained from the Agricultural Support Republican Centre. It has been found out that majority of farmers that participated in the Technology Evaluation Programme had increased productivity, had less post-harvest loss, produced high quality and safe output, and increased income accompanied by better welfare. However, new laws and regulations for shared roles and responsibilities of involved institutions are recommended. Farmers from isolated areas should also be engaged within the scope of the project, and promotion of nationwide awareness of the program should also be carried out to the end users.
\end{abstract}

Keywords: innovative technologies, sustainable agriculture, Armenia, adoption and productivity

\section{Introduction}

\section{Overview of agricultural production and Armenian economy}

The republic of Armenia occupies an area of 29,800 square kilometres. It is located in the verge of the Southern Caucasus and Asia Minor, in the northeast part of the Armenian Plateau. The average altitude is 1,800 meters above sea level (Avetisyan, 2010). The population of Armenia is about 3 million, out of which $98 \%$ are ethnic Armenians (World Bank, 2014).

Armenia is an upper-middle-income country with a small-sized economy. Armenia has the world's $140^{\text {th }}$ largest economy by nominal GDP which in 2013 with the $3.5 \%$ growth was $10.4 \$$ billion (World Bank, 2014). Food and agriculture sector is one of the most important industries in Armenia's economy. The role of the agrarian sector has been critical from the perspectives of the country's economic development, food safety, and overcoming rural poverty (Avetisyan, 2010). It is remarkable that prior to the collapse of the Soviet Union, Armenia had made unprecedented steps towards agrarian reforms (Avetisyan, 2010). Soon after independence in 1991, Armenia took steps to liberalize its economy in general, and the agricultural sector in particular, by introducing major reform programmes. The Armenian land privatization programme is unique among former Soviet Republics in regard to the speed and completeness of its implementation. At the request of the Government of Armenia, to ensure the successful implementation of these programmes, an FAO/CP mission visited Armenia in April/May 1994 and assisted the Government in identifying a project that would support the agricultural reform programmes. A mission from the World Bank visited Armenia in May/June of 1993 and prepared a review of the sector (APIU, 2013).

In 2013, together with the associated agro-processing, the sector accounted for about $20.6 \%$ of GDP, $17 \%$ of export earnings, and about $44 \%$ of employment. The fast economic growth over the last decade has generated new opportunities for the agriculture sector, which has grown at a robust rate, averaging at more than $6 \%$ annually since 1997 despite the downturn in 2009-2010 (CIA-The World Factbook, 2013). Exports of agricultural products have doubled since 2005, mostly beverages and to a lesser extent fruit and vegetable products, although there was a significant but proportionally small increase in the export of live animals in 2011. However, the sector has not been able to fully take advantage of opportunities, with expanding consumer demand partly met by a substantial increase in imported products, which has outweighed exports and resulted in a steadily increasing gap between imports and exports and a widening of the agro-food deficit (APIU, 2013). Overall, Armenia is a net importer of agricultural products with imports of US\$700 million in 2011 compared with exports of about US\$ 230 million (APIU, 2013). Manufacturing and industry in Armenian economy account for $37.3 \%$ of GDP and employ $16.80 \%$ of the population. The service sector accounts for $42.1 \%$ of the GDP and employs $39 \%$ of the population (CIA-The World Factbook, 2013).

In the agricultural production sphere, the main land users are private farmers who own $71.7 \%$ of privatized arable lands, $78.3 \%$ of perennial crop areas, and $48.4 \%$ of grasslands. As a result, the private sector produces over $98 \%$ of the gross agricultural product (Avetisyan, 2010). Until now, with the help of international organisations, the Armenian government has been implementing a variety of projects and investments which cover all sectors of agriculture. It is worth mentioning that at the beginning of 2000 s government started prioritizing the investment of agricultural technologies in rural areas. In 2001, the government of Armenia with the help of the World Bank started implementing new project which was called the Technology Evaluation Programme (TEP). After a decade, the results of invested technologies in agriculture were obvious and the role of new and advanced technologies also found its place in 2010-2020 strategy of sustainable development of rural areas and agriculture in the Republic of Armenia (RA). The document reflects the priority directions of agricultural policy and the strategies of implementation. 
The focuses of the strategic policy document are:

1. To overcome the consequences of financial crisis and apply new anti-crisis mechanisms.

2. To deepen agrarian reforms and develop agricultural cooperatives.

3. To ensure high level of food safety in the country, self-sustainability in the vital food products.

4. To increase the competitiveness of domestic products and development of export-oriented products.

5. To reach sectorial specialization and the optimal distribution of products.

6. To increase the land use efficiency.

7. To develop organic agriculture.

8. To develop crop production:

$\square$ investment of advanced technologies,

$\square$ prevalence of value added agricultural products within the crop production,

$\square$ development of seed production and selection systems, investment of new mechanisms for seed quality control,

$\square$ crop protection and implementation of quarantines,

$\square$ genetic diversity of crops and protection of wild spices.

9. To develop animal husbandry:

$\square$ support for efficient and rational allocation of couples in livestock sectors,

$\square$ breeding development and implementation of complex activities for flock reproduction,

$\square$ improvement of the efficiency of veterinary projects and services,

$\square$ development of animal feed base by creating small feed production units in all regions of Armenia,

$\square$ support to the development of livestock trade organizations,

$\square$ conservation of genetic diversity of farm animal races.

10. To develop processing of agricultural raw materials:

$\square$ development of the sphere by optimal distribution of processing companies,

$\square$ application of advanced technologies and improvement of the products' competitiveness,

$\square$ market support and development of contract relations among processing companies,

$\square$ development of production technologies.

11. To develop social infrastructure in rural areas.

12. To reduce risks in agriculture.

13. To improve access to credit facilities in agriculture.

14. To improve knowledge, science and advisory system.

15. To improve agricultural farm record system (ARLIS, 2010).

\section{Agricultural technology in Armenia}

Improvement of agricultural technology is a focal point and its application to ensure an increase in agricultural production is key in the above mentioned policy directions of the agricultural policies and strategies in the RA. The world's population will climb to over 9 billion in the coming years, with nearly all of the growth occurring in less developed parts of the world where agricultural productivity is relatively low, such as the Sub-Saharan-Africa, Asia and South America (GHI, 2011). This population boom will be accompanied by increased strains on our food supply and resources, causing increased pressure on already delicate political and ecological systems, as well as threats to global food security.
As a result, the need has never been greater for innovative technologyoriented solutions that will lead to significant improvements in our food and nutritional security, including greater investment in science and technology. Overtime, scientific and technological advancements have benefited farmers in the industrialized world by driving agriculture production. However, smallholder and medium scale farmers who are responsible for about $80 \%$ of the food in the developing world and specifically more than $90 \%$ in Armenia, have yet to experience similar gains (IFAD, 2011). These farmers lack access to many of these improved technologies such as modern irrigation practices, crop management products, fertilizers, postharvestloss solutions, improved seed varieties, mobile technologies, as well as access to information and extension services that are liable to boost agricultural technology in Armenia. Greater investments in agriculture technologies, increasing productivity yield, quality and conservation, reduction of postharvest-losses and food wastage, access to real-time and innovative information and services are needed to afford agricultural sector a more sustainable approach to attaining food security, therefore, curbing hunger and malnutrition in Armenia (IFPRI, 2002).

This needs a broader use of and investment in science-based-innovative technologies to bring about improved livelihoods of farmers and their families by producing more and higher quality crops for national population; enhanced nutritional value and safety of food to improve the health and well-being of people; and agricultural sustainability through efficient resource use. There has been an increasing demand for food in the Republic of Armenia over years, which has created a gap due to inability of the National Food Supply System to overcome the challenge (UN, 2013). There must be imminent works to meet national food demand through science-based innovation that reaches farmers, particularly smallholder ones. Nearly every industry has experienced scientific advancements that have led to profound achievements, and in many cases, have enabled us to solve some of the globe's biggest challenges. Innovation in the agricultural industry offers a similar promise of improving farmers' lives, feeding and nourishing more of our population, and consequently, improving the political, ecological, and economic stability of the nation. As the natural resources of the world are being depleted, the equivalent of a planet and a half of resources are already been used up (WWF, 2012). Consequently, farmers need access to seeds that use fewer resources and that are better for the environment, as well as other tools and agronomic practices that enable them to produce more with less. The food system of the future will look different than it does today. People have been increasingly moving away from where food is grown and are less aware of how it is grown. By 2050, an estimate of $70 \%$ people will be living in urban areas, creating the need for processing and storage technology, sound infrastructure, efficient distribution channels, and open trade policies (FA0, 2009).

The development and use of agricultural technology is not, however, limited to genetic strategy. Indeed, the use of computational technology combined with geographical location devices and remote sensing advancements promise to radically change the way all crops will be managed (Káposzta and Nagy, 2005). Commonly referred to as "Precision Agriculture", the underlying theme is integration of information to create management knowledge as a means to address site-specific production goals. Uncertainty with the environment will always be a key issue with agriculture, but this too will be managed as environmental modeling, combined with risk management algorithms, it will lead to the optimal use of genetics on specific soils within known weather profiles. And, breakthroughs will continue to be seen in the "classical" technologies that have exponentially increased world food production since the advent of 
"scientific agriculture" in the late 1800s (Scott, 2013).

In addition to advances in productivity, technology will be used to remediate land that has been overused or misused through poor agricultural practices. Climate change and increasing weather volatility will drive demand for new seed technology adapted for unfavourable conditions and stressed land. However, there are many barriers impeding the adoption of these tools, including a lack of uniform and consistent regulatory frameworks and intellectual property protections, general lack of understanding of potential of science and technology, the inability of smallholder farmers to access finance and capital to invest in technology to adjust to the effect of climate volatility as well as to improve their yields (Paul and David, 2012).

Despite these challenges, agricultural technologies have played a central role in overcoming food security challenges in the past. The $20^{\text {th }}$ century marked a time of significant public investments in scientific research that contributed to historical increases in food production (IFPRI, 2002). New discoveries in last century contributed to historical increases in food production during a time of widespread hunger and malnutrition. For example, the adoption of high-yielding varieties of rice and wheat, the expansion of irrigation infrastructure, and the use of other inputs more than doubled cereal production in Asia between 1970 and 1995. As yields increased, farmers quickly adopted these technologies, resulting in increased profitability and incomes. Over the years, irrigated land has proven to be twice as productive as rainfed farmland. This will be particularly important in the coming decades given that an estimated 1.8 billion people will live in water scarce regions by 2025 (The DUPONT, 2012). Similarly, mobile technology can enable farmers to increase their yields by connecting them through text messages and help lines to agricultural market information, best practices, and extension services designed to meet their localized needs. Fertilizers have also contributed to doubling and tripling crop yields, supplying crops with the essential nutrients missing from soil, as well as facilitating the more efficient use of land and water. And, with advances in mechanization, farmers can more efficiently tend to their crops and produce more with less manpower. Today, farmers are even using precision farming solutions, such as global positioning system (GPS) technology, to increase yields while using fewer inputs, leading to estimated productivity gains of $10 \%$ and an average input savings of $15 \%$. Agriculture footprint on our ecosystem is substantial. In fact, agriculture consumes 70\% of our world's water for the irrigation of crops (The DUPONT, 2012).

However, advancement in agriculture technology is a key to improvement of agricultural production. Resistant seed varieties, through crop improvement, are better adapted for volatile climates and also are drought resistant, as well as technology improves modern irrigation practices to enhance adoption by crops during dry seasons when water is scarce and water surface is very low. To this end, the concept of the application of technology will be central to enhancing sustainable agriculture. Studying the role of new technologies in the world, it is clear that technologies based on science have their great impact on increase of productivity and on sustainable agriculture. The role of new and innovative technologies is also given a priority in Armenia. It is against this background that this study examined the impact of the Technology Evaluation Programme on agricultural production.

\section{Materials and methods}

The data used in the study basically comes from secondary sources over the period of 2001-2013 (12 years), mainly from the statistical bulletin of the Armenian Statistical Service and the Agricultural Support Republican Centre. The selected years for the studies were chosen due to the period of implementation of the programme which spanned through 2001-2013, and availability of the data.

The publication is designed to serve as an easy reference for statistical information and sources. The dataset provides detailed records on total agricultural output, agricultural crops, livestock and poultry products, heads and land area for crop production. Descriptivestatistics, such as graphical illustrations, percentages, frequencies and pie charts were used to describe and examine the trends of the above mentioned parameters over the years understudy. Furthermore, we employed narratives to describe the effects of the Technology Evaluation Programme on agricultural production in the RA. This scope of the study only covered the implementation and post-implementation period of the Technology Evaluation Programme leaving out the pre-project (baseline) status of agricultural production in the RA which could have served as a basis for comparison of the impacts of the project.

\section{Results and discussion}

As illustrated in Figure 1, agricultural crop production in the RA experienced fluctuation in growth patterns from 2001-2013. Among main cultivated crops in Armenia, the highest growth was marked in vegetable production. In contrast, water melon showed slight increase by showing the lowest production. Main production falls happened during the period of 2010-2011. Only the grape production did not show sharp fluctuations during the last decade and grew steadily. All in all, crop production sub-sector experienced an increase in the level of output

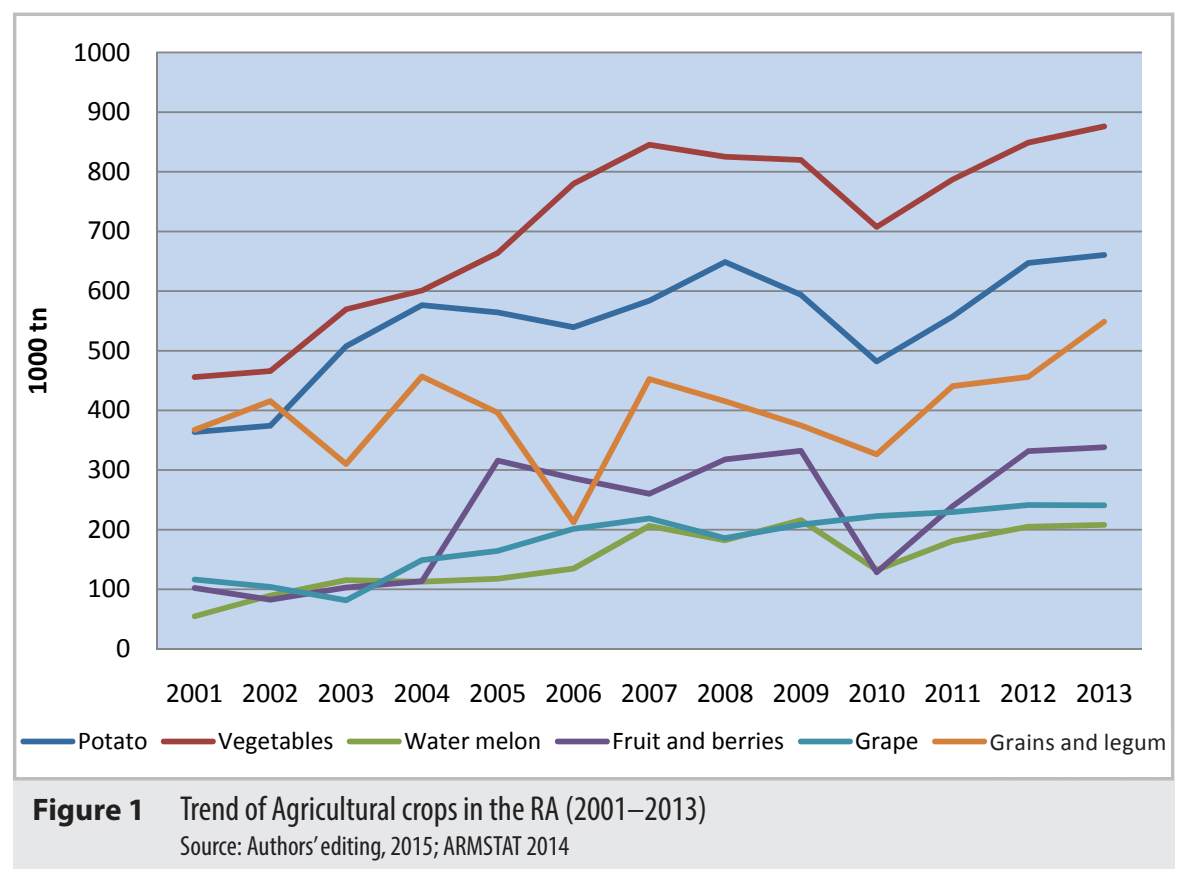




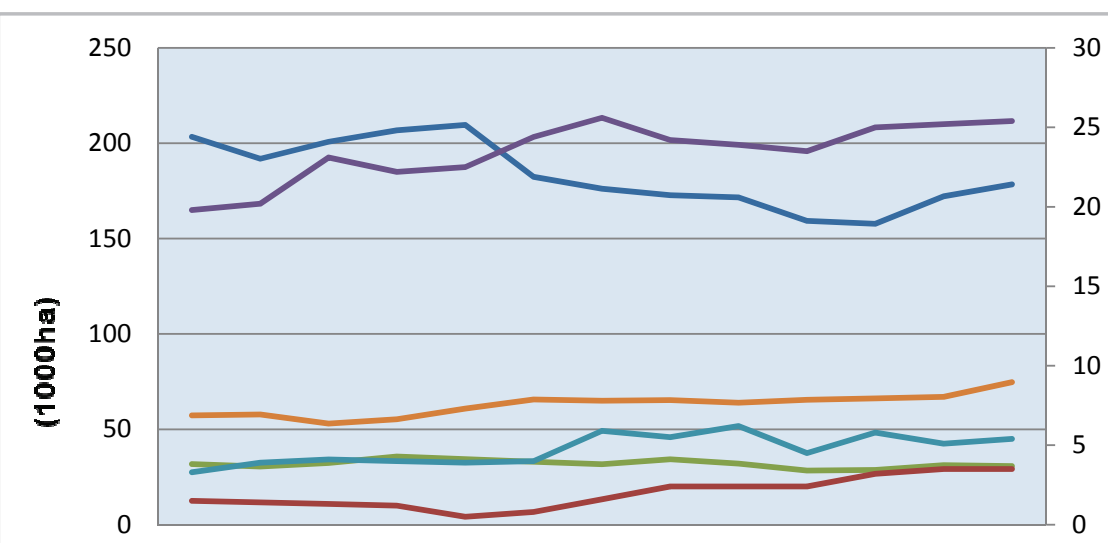

2001200220032004200520062007200820092010201120122013

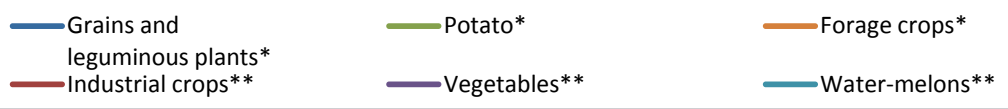

Figure 2 Land areas for crop production in the RA (2001-2013)

Source: Authors' editing, 2015; ARMSTAT 2014

${ }^{*}$ left vertical axis; ${ }^{* *}$ right vertical axis

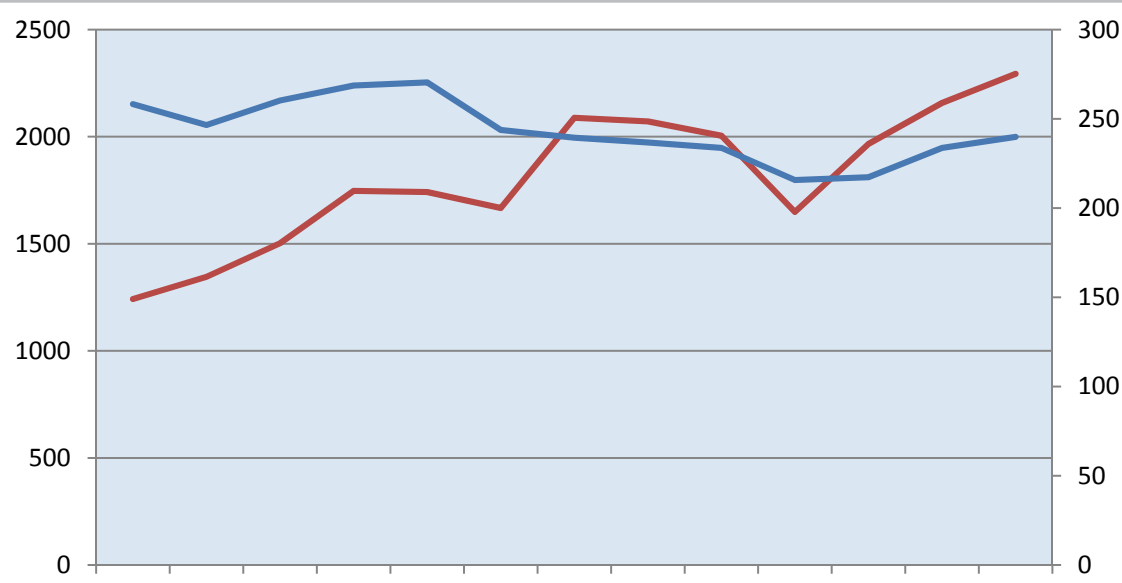

2001200220032004200520062007200820092010201120122013

Cutput(1000tn)* ${ }^{*}$ Land area(1000ha)**

Figure 3 Comparison in trends of land area and agricultural output (2001-2013) Source: Authors' editing, 2015; ARMSTAT 2014

*left vertical axis; ** right vertical axis

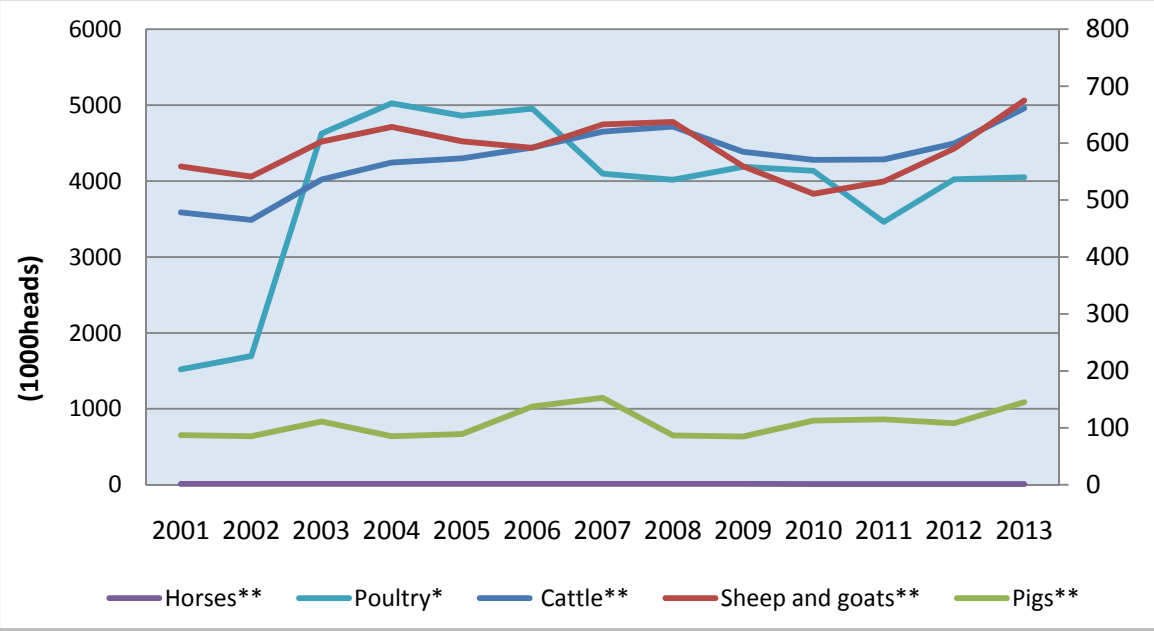

Figure 4 Trends of Livestock and Poultry heads in the RA (2001-2013)

Source: Authors' editing, 2015; ARMSTAT 2014

${ }^{*}$ left vertical axis; **right vertical axis across the years. This increase is largely connected with the high adoption of innovative technologies such as high yield seed varieties, insectisides, pesticides and bio-fartilizers, which improved farmers' output in RA.

Armenia is a country with lots of mountainous areas with lack of land resources. As a result of this condition, the TEP has made available various less-water demanding seed varieties that can be cultivated in submountainous and mountainous areas feasible, therefore maximizing the use of available arable land area for agricultural purposes.

Prior to the implementation of the TEP in 2001, there is a marginal increase in the land use productivity in crop production in the RA (ARMSTAT, 2014). Figure 3 illustrates that there is more than proportional increase in crop output compared to the land area cultivated across the years understudy. The needs of the farmers, especially the rural farmers, are identified and innovative technologies are developed through the analysis of scientists and researchers to attend to these needs. This has improved the productivity and efficiency of land resources and farm inputs, which resulted in persistent growth of output.

Figure 4 shows the trend of livestock and poultry heads across the project years. The numbers of poultry at the beginning of the project years significantly and gradually increased. There is a slight increase in the numbers of sheep, goat and cattle, while the numbers of pigs remained nearly the same. As a result of lack of adoption by farmers, the numbers of horses did not record any significant change. In summary, variation in the growth of different animals in the livestock sub-sector is significantly affected by the rate of adoption of the TEP by these farmers.

Figure 5 shows that there is a considerable growth in the major products and by-products from livestock and poultry from the beginning of the project years and beyond. This increase can be attributed to the innovative technologies offered in the scope of the Technology Evaluation Programme which was adopted by livestock farmers in all regions of Armenia where this project was intensively implemented.

\section{General description of the Technology Evaluation Programme}

The Technology Evaluation Programme exhibits technologies through the help of field days, workshops and experiments. These innovative technologies depend on the needs of farmers in a particular rural area. Farmers have clear perception about their situation and status. The Technology Evaluation Programme allows them 


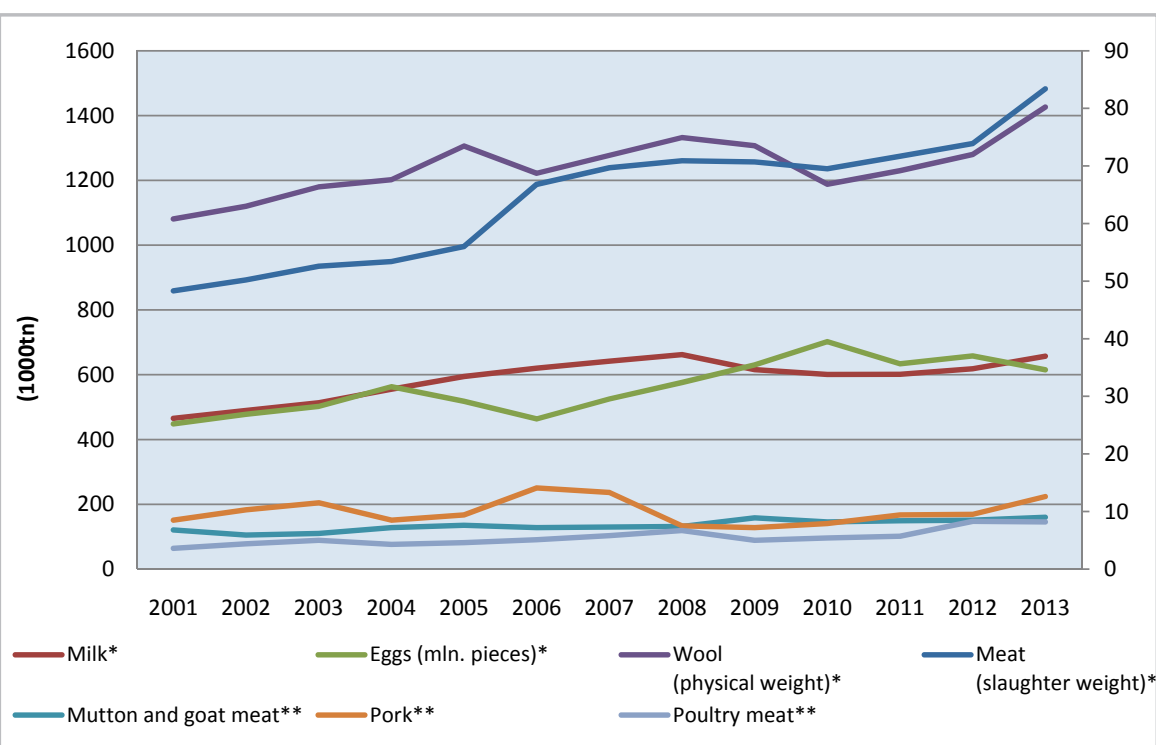

Figure 5 Trend of Livestock and Poultry products in the RA (2001-2013) Source: Authors' editing, 2015; ARMSTAT 2014 *left vertical axis; ;* right vertical axis

to develop their perception through the analysis of scientists and researchers. It is being implemented by mutual efforts, by practical experiments which are aimed to figure out successful innovations. Sometimes, the technologies are not totally new, but the result can be a new combination of several elements or rearrangement of elements from previous successful technologies. This will provide a platform for development of relationship between farmers, researchers and scientists as a result of the programme being implemented. Sometimes, the relationship of farmers and scientists needs to be improved, which is efficiently being implemented with the help of extension agents (Hayrapetyan and Muradyan, 2011).

The Technology Evaluation Programme follows 3 main purposes:

$\square$ To give an opportunity for farmers to gain proper knowledge of using innovative technologies. It is expected that the technology will result to the growth of the household's income; it would bring long term environmental and economic sustainability.

$\square$ To reach the expected results, to implement the demanded amount of technologies and to make farmers understand the procedures of implementation and replicating through the help of extension agents.

$\square$ To promote other farmers (initial nonbeneficiaries) who live in the same area to replicate the technologies. impacts:

The project can have the following extra

$\square$ Creation of mutually beneficial relations and ensuring the feedback between researchers, extension agents and farmers.
The program finances the experiments, in which technologies:

$\square$ contribute to the growth of farmer's income and the commercialization of particular economy,

$\square$ can be replicated from the farmers living in the same area,

$\square$ do not have negative impact on the health and social welfare of family members, as well as on environment.

\section{Institutions that are involved in agricultural support programs in Armenia and their role in creation, investment and proliferation of innovative technologies}

The evaluation of technologies is a chain where each organization has its mission and range of activities. In the context of technology investment, a mechanism is suggested where new and existing technologies are invested in and evaluated among the farming households. The programme fosters and promotes the linkage between knowledge and production. First needs of farmers are introduced to the Agricultural Support Republican (entre by Agricultural Support Regional Centres (Figure 6). Then, the needs are introduced to Scientific Centres. Taking into consideration first needs, scientific centres introduce technologies which they think are suitable for implementation and will satisfy farmers' needs.

Afterwards, the process of comparison of needs and technologies starts. Agricultural extension agents, experts from scientific centres and other beneficial people discuss the technologies and choose the one which is suitable to satisfy the priority needs of farmers (Hayrapetyan and Muradyan, 2011). After the above mentioned procedures, the specialists of Agricultural Support Regional Centres start choosing the farms where the technologies are going to be invested. It is worth mentioning that the specialists give priority to those farmers who are highly educated, have enough resources, agricultural machineries, big plots, additional instruments that can be useful for investment of technologies, and the most important factor is their willingness to accept and to spread it among other farmers. During the same period, a researcher is working on a suggested technology, coordinating it with the Agricultural Support Republican Centre, which in turn makes necessary corrections, constructs an implementation period and main elements of a budget. The financial part of the programme was supported by the Project Implementation Unit (75\%) and the rest 25\% was provided by farmers (Hayrapetyan and Muradyan, 2011). During the project implementation, field days, seminars are being organized, at the end of the project; organisers create informative flyers and disseminate them among farmers.

\section{Main directions of the program implemented in Armenia}

Since 2001, Agricultural Support Regional Centres started implementing the Technology Evaluation Programme, which is being coordinated by the Knowledge and Innovation Department of Agricultural Support Republican Centre. The programme with its character is innovative and based on the priority needs of households.

During the period 2001-2013, more than 1,000 projects were implemented. The projects had the following directions (Figure 7):

$\square$ agricultural crop production,

$\square$ crop protection from pests and diseases,

$\square$ cultivation of grape and other seeded fruits,

$\square$ animal husbandry and veterinary services.

Researches have shown that Technology Evaluation Program ensured high efficiency. For that particular point, we want to describe some successfully accomplished projects that were implemented in scopes of the programme. Below there are some projects implemented on the TEP in Armenia: 


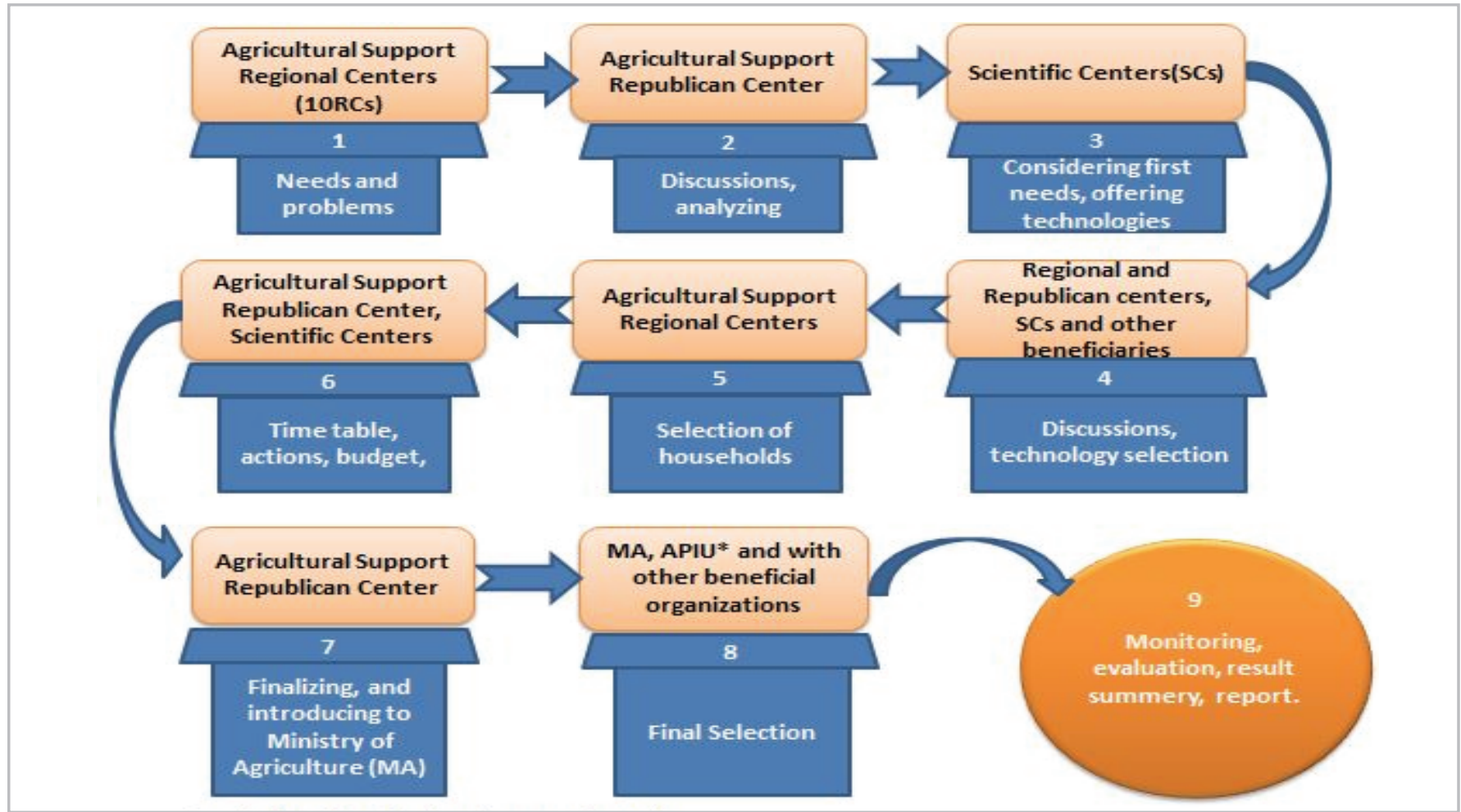

Figure 6 Steps of project implementation Source: Authors' editing, 2015 *agricultural project implementation unit

\section{Investment into local small-seed lentils cultivation technology}

Area of Implementation:

$\square$ Village Fontan, Province Kotayk, City Hrazdan

\section{Description}

Being a drought resistant, less soil nutrients demanding and having a short vegetation period (80-90 days), lentils can successfully be cultivated in sub-mountainous, mountainous and nonirrigated areas and get from 2-2.5 tons harvest from a hectare. Using advanced technology of cultivating local small-seed, drought resistant, short growing (30-35) lentils with all necessary measures, it is estimated to obtain up to 2-2.2 tons ha ${ }^{-1}$ harvest and $1-1.5$ tons ha $a^{-1}$ high quality thatch, which will bring more than 950-1200 EUR profit from 1 ha.

\section{Results from one hectare}

In the autumn, there was done deep tillage of the soil and inserted $300 \mathrm{~kg} \mathrm{ha}^{-1}$ potassium and 500 $\mathrm{kg} \mathrm{ha}^{-1}$ phosphoric fertilizers. During the presowing time in spring, loosening, raking and sowing was done. After sowing, the farmland was protected against weeds using Valsatop preparatory $\left(3.5 \mid \mathrm{ha}^{-1}\right)$. Harvesting started a little earlier than usually, when the beans were getting darker. As a result, the indicator of beans showed 1.5 times more result than at traditional practices. This means $47.3 \%$ more yield from a hectare. Overall, in unirrigated conditions the cultivation of lentils gives us an opportunity to get 2 tons of beans and 1.2 tons of thatch from 1 ha. The extra cost of beans exceeds the expenditure on procedures (ASRC, 2014).

\section{Investment into a new preparatory to combat pests and diseases of cucumbers}

Area of Implementation:

$\square$ Village Arevabyur, Province Ararat

\section{Description}

Investment into advance technology is meant to increase householder's income and improve the appearance of the product. The invested technology made it available to all farmers through the seminars, exhibitions and information flyers. It is expected to get $20-25 \%$ additional harvest from the cultivation of cucumbers.

\section{Results}

According to the new technology, during the whole injection period, 'Silvet Gold' preparatory (3 $\mathrm{ml}$ on $10 \mathrm{~L}$ water) should be added to all working preparatories, which contribute the

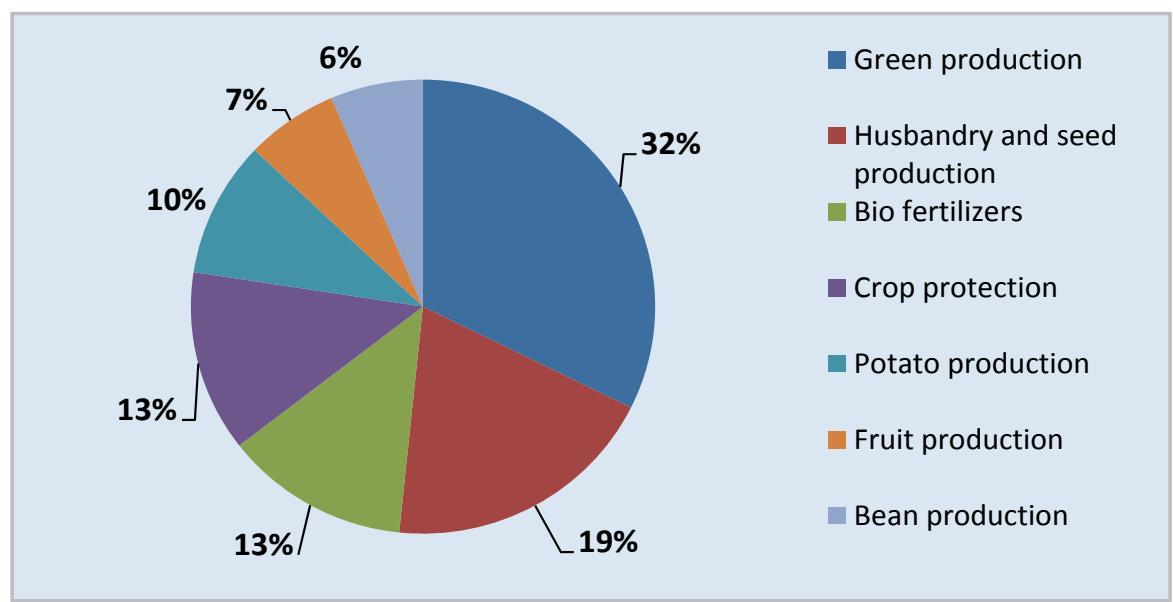

Figure 7 Main directions of the Technology Evaluation Programme in \% Source: Authors' editing, 2015 
proliferation of the liquid on a crop. The experiment was carried out on Natasha F1 cucumber to struggle against pests and mildew. The adoption of this new technology resulted in increasing the net income of farmers by 1,300 EUR and $134.3 \%$ level of profitability (ASRC, 2014).

\section{Investment into'Flor Humat' bio-fertilizer in the fields of watermelons}

Area of Implementation:

\section{Description}

$\square$ Village Mrgashat, Province Armavir.

Investment into technology contributed to high quality of watermelons, which can bring extra profit to households of up to $20 \%$.

\section{The results from 0.5 ha}

The results of the implemented technology showed that Flor Humat biofertilizer accelerated the intergrowth of seeds, promoted the growth, development and the increase of the crop production. Without the particular fertilizer, the harvest was $20,000 \mathrm{~kg}$ from 1 ha. After using 'Flor Humat' biofertilizer, it increased by $20.5 \%$. In addition, the cost of production dropped and increased the net profit by $39.9 \%$. The profitability level was $113.5 \%$, while the traditional one was $84.4 \%$ (ASRC, 2014).

\section{Investment into usage of 'Azoceovit 1' bio-fertilizer in potato fields \\ Area of Implementation: \\ $\square$ Village Mantash, Province Shirak.}

Estimating the soil-climatic conditions of the region it was suggested to invest into the use of 'Azoceovit-1' bio-fertilizer. It is predicted that after all successfully implemented actions against the pests, the result should bring 40-60\% additional ecologically cleaned potatoes.

\section{The results from 0.2 ha}

The multiple effect of fertilizer, first of all, is coming from its unique feature of microbes, which shows triple effect by enriching the soil with biological nitrogen and producing antibiotics that make pressure on the growth of disease viruses in soil. From the experimental version, farmers that adopted this technology have average yield of $3,910 \mathrm{~kg} \mathrm{ha}^{-1}$ while non-adopters obtained 3,890 $\mathrm{kg} \mathrm{ha}^{-1}$ harvest (ASRC, 2014).

\section{Introduction of new varieties of edible kohlrabi in pre-mountainous conditions}

Area of Implementation:

\section{Description}

$\square$ Village Verishen, Province Syuniq.

This technology suggested the cultivation of edible kohlrabi 'Giant-late' ripening and 'Ruski razmer' mid-ripening varieties. These varieties in bioclimatic conditions have not fully maintained their variety qualities and have differed from each other in phonological and bio-morphological characteristics. 'Giant' and 'Ruski razmer' varieties have ensured per 1 ha 480.0 and 320.0 canter yield, respectively. The levels of profitability from cultivation of these two varieties are 114 and $221 \%$, respectively. Both studied varieties are stable, have high taste and qualitative properties and can present valuable fodder raw material for agricultural animals (ASRC, 2014).

\section{Application of new efficient system for control of adverse organisms /weeds, pests, diseases/ of sugar-beet \\ Area of Implementation: \\ $\square$ Village Hatsik, Province Shirak.}

\section{Description and expected results}

Sugar-beet fields will be cleaned of all types of weeds after the implementation of the new system. The results will be maintained not only during the experimental year but also the following year. Two inter-row cultivations will be reduced. Additional yield of sugar-beet edible roots compared to the control one will comprise $6,000-6,400 \mathrm{~kg} \mathrm{ha}^{-1}$. Beneficiaries will get 35-40 EUR profit from spending 1 EUR for the implementation of the new system.

\section{Results from (0.6 ha)}

As a result of the technology implementation, the yield of beet root crop has comprised 10 tons $400 \mathrm{~kg}$, and from sample plot- 12 tons $600 \mathrm{~kg}$. The productivity indicators per $1 \mathrm{ha}$ are the following: control $-35,000 \mathrm{~kg} \mathrm{ha}^{-1}$, sample $-42,000 \mathrm{~kg} \mathrm{ha}^{-1}$. The increase of beet yield has comprised 7,000 kg ha-1 . During the beet cultivation, weed control has been conducted through Dual Gold and Fusillade herbicides and pest control through the application of Triumph fertilizer. The net income of the farm has comprised 3,550 EUR and the level of profitability was $274 \%$ (ASRC, 2014).

\section{Conclusions and recommendations}

The importance of agricultural technology in the RA cannot be overemphasised, as agriculture contributes to relatively high share of the GDP. Considering this importance, the government of the RA has implemented this initiative (TEP) in order to improve agricultural productivity and farmers' welfare. However, taking into account the fact that the TEP ended in 2014, it marked a number of successes and failures in terms of processes of program implementation and increasing agricultural output. Therefore, the study examined the impact of the Technology Evaluation Programme on the agricultural productivity in Armenia over the implementation period (2001-2013) using descriptive analysis to examine the trends of agricultural productivity through the programme period. Also, the process of implementation of the programme and the institutions involved were also examined. Overall, the findings in this study indicate that adoption of the TEP helped to raise farmers' productivity which has potentially improved the farmers' income and per capita expenditures, thereby increasing their probability of escaping poverty.

This confirms the widely held view that productivity-enhancing agricultural innovations can contribute to raising incomes of farm households, poverty alleviation, and food security in developing countries. However, this study suggests that such programmes should be implemented continuously and should emerge from the first needs of farmers, because they foster the development of sustainable agriculture. In addition, to combat the uneven distribution of these innovative technologies to the farmers who are in isolated areas, the project coordinators should ensure the participation of these farmers. Furthermore, it is recommended that effective monitoring and evaluation mechanism should be put in place by the Project Implementation Unit (PIU), which is in charge of funds management. This will ensure that the project objective is well-implemented according to the project proposal in order to achieve the proposed goals and objectives. Also, the monitoring and evaluation of the project's effect should start with project implementation and post-project implementation, in order to make sure that farmers continually improve their existing and new streams of income. Finally, to promote further participation of the farmers, a national platform should be created for communicating technological improvements and their adoption through the use of mass-media (Radio, TV, and the Internet). Effective awareness strategies about new and innovative technologies can also be adopted by agricultural extension agents, in order to proliferate the programme to the 
end-users (farmers) by increasing the frequency of workshops, field days, seminars and informative flyers.

\section{Acknowledgment}

We acknowledge the following offices in the Republic of Armenia: the Armenian National Statistic Service, the Agricultural Project Implementation Unit and the Agricultural Support Republican Centre for provision of qualitative and quantitative data that was used for this research study. We also appreciate the contributions of reviewers of 'Euro Land 2015' seminar for top quality review that was made when this paper was submitted for presentation in the seminar.

\section{References}

AGRICULTURAL PROJECT IMPLEMENTATION Unit-APIU. 2013. Report on CARMAC I project. Available at: http://www.arspiu.com/CARMAC-II-PROJECT.55.0.html?\&L=0

AGRICULTURAL SUPPORT REPUBLICAN CENTRE-ASRC. 2014. Official bulleting of New Agricultural technologies. Available from: $h t t p: / / a s r c . a m / i n d e x . p h p ? i d=4151$

ARLIS. 2010. 2010-2020 Strategy of sustainable development of rural areas and agriculture: The act of Government of Armenia. Available from: http://www.arlis.am/ DocumentView.aspx?DoclD=63109

AVETISYAN, S. 2010. Agriculture and Food Processing in Armenia. Limush Publishing House, Yerevan, 2010. $138 \mathrm{p}$.

CIA The World Factbook. 2013. https://www.cia.gov/library/publications/the-worldfactbook/geos/am.html

DOBÓ, E. - SINGH, M. K. - TÓTH, T. - KÁPOSZTA, J. - FEKETE-FARKAS, M. 2008. Measuring agricultural crop vulnerability, sensitivity and adaptivity in Ceecs, Cereal Research Communications, vol. 36, 2008, no. 1, pp. 1291-1294.

FA0. 2009. A Third More Mouths to Feed. Available at: http://www.fao.org/news/story/en/ item/35571/icode/. (Sept. 23, 2009)

GHI. 2011. Global Agricultural Productivity (GAP). Report available at: http://www. globalharvestinitiative.org/index.php/2011-gap-report/

HAYRAPETYAN, A. - MURADYAN, M. 2011. Peculiarities, implementation, estimation and dissemination of advanced agrarian technologies in farms of Marzes of the RA. In Agricultural Knowledge, Yerevan, vol. 5-6, 2011, pp. 279-284.
INTERNATIONAL FOOD POLICY RESEARCH INSTITUTE - IFPRI. 2002. Green Revolution Curse or Blessing? Available at http://www.ifpri.org/sites/default/files/pubs/pubs/ ib/ib11.pdf

INTERNATIONAL FUND FOR AGRICULTURAL DEVELOPMENT-IFAD. 2011. Environment and Natural Resource Management Policy: Resilient Livelihoods Through the Sustainable Use of Natural Assets, 2011. Available at http://www.ifad.org/gbdocs/eb/102/e/EB2011-102-R-9.pdf

KÁPOSZTA, J. - NAGY, H. 2005. A mezőgazdaság fejlesztési lehetőségei megyei vizsgálatok alapján. In Gazdálkodás, vol. 49, 2005, no. 4, pp. 51-55.

NATIONAL STATISTICAL SERVICE OF REPUBLIC OF ARMENIA-ARMSTAT. 2001-2014. Statistical Yearb------00k of Armenia.

POLMAN , P. - SERVITJE, D. 2012. The Global Challenge of Food and Nutrition Security, the Washington Post, June 17. Available at: http://www.washingtonpost.com/opinions/ the-global-challenge-of-food-andnutrition-security/2012/06/17/gJQAWse1jV_ story.html

Scott, H. 2013. The Role of Technology in Sustainable Agriculture. IPM World Textbook. Available at: http://ipmworld.umn.edu/chapters/hutchins3.htm

The DUPONT. 2012. The role of technology in agriculture: The DUPONT advisory committee on agricultural innovation and productivity for the $21^{\text {st }}$ century: Available at: http:// foodsecurity.dupont.com/wp-content/uploads/2012/07/DuPont-AgricultureCommittee-The-Role-of-Technology-in-Agriculture.pdf

United Nation (UN). 2013. Sustainable Development Challenges Sustainable Development Challenges. World Economic and Social Survey 2013, Department of Economics and Social Affairs, 2013. pp. 21-22.

World Bank. 2014. Country program snapshot: World Bank Group - Armenia Partnership, 2014. pp. 2-4. http://data.worldbank.org/country/armenia

WORLD WILDLIFE FUND (WWF). 2012. Biodiversity, Biocapacity, and Better Choices. Living Planet. Report available at: http://awsassets.panda.org/downloads/1_Ipr_2012_ online_full_size_single_pages_fina.I_120516.pdf

\section{Contact addresses}

Davit Alaverdyan, Szent István University, Faculty of Economics and Social Sciences, 1 Páter K. str., H-2100 Gödöllő, Hungary, e-mail: alaverdyandavid001@gmail.com 